Osmangazi Tip Dergisi/Osmangazi Journal of Medicine, Mayıs/May, 2016;38 (2), 78-80

DOI: http://dx.doi.org/10.20515/otd.91929

\title{
How to Resect a Mediastinal Parathyroid Adenoma
}

\author{
Bartu Badak, Necdet Fatih Yaşar \\ Eskisehir Osmangazi University, Faculty of Medicine, Department of General Surgery \\ *email: drbartu@gmail.com
}

A 60 year old woman had a history of fatigue and nephrolithiasis. Her serum calcium and parathyroid hormone levels were $11.45 \mathrm{mg} / \mathrm{dL}$ (8.6-10.2) and 464,7pg/mL (15-65) respectively. Her tubular phosphate reabsorption rate was $56 \%$ while her chloride/phosphate ratio was 69,9. Her neck USG was normal. A parathyroid scintigraphy revealed a mass extending from lower pole of the left thyroid lobe to the mediastinal region with tracer retention. CT scan of neck and thorax verified the mass below the aortic arch, which was nodular, isodense with the thyroid gland and measured approximately 26x27 mm and detected another hypodense nodule within this bigger nodular mass measuring $13 \times 11 \mathrm{~mm}$.

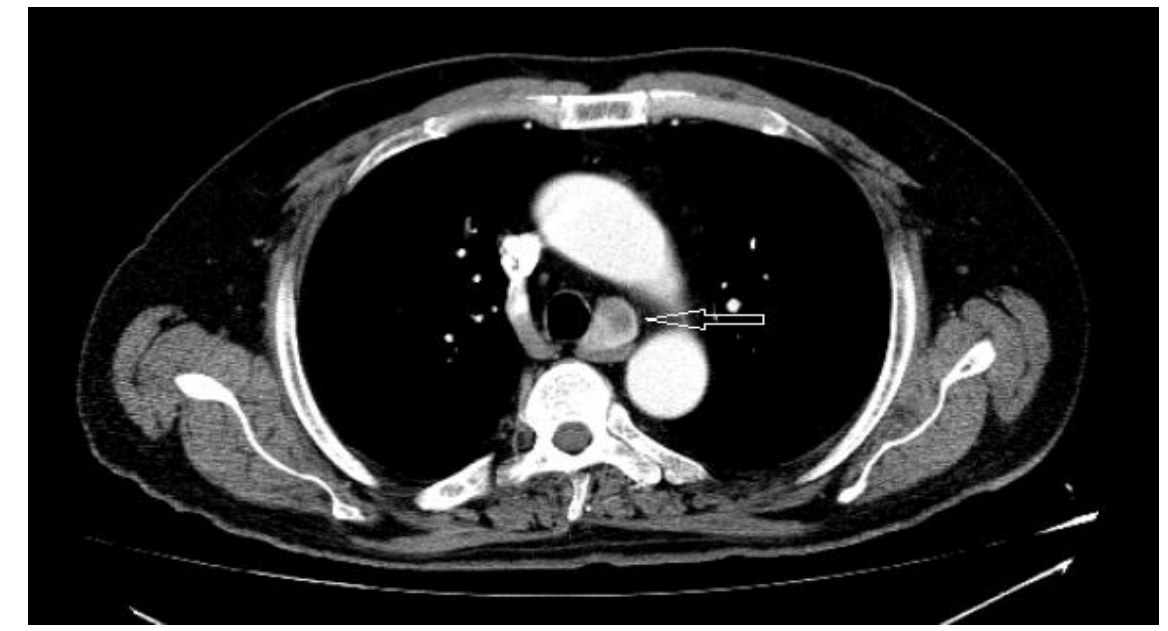

Figure 1: Parathyroid adenoma in computerised thomography

This mass was connected to left thyroid lobe by a tubular tissue. These findings were interpreted as consistent with mediastinal parathyroid adenoma. During the surgery, after the upper pole of the adenoma was explored, it was resected with blunt dissections using the balloon of a foley catheter 


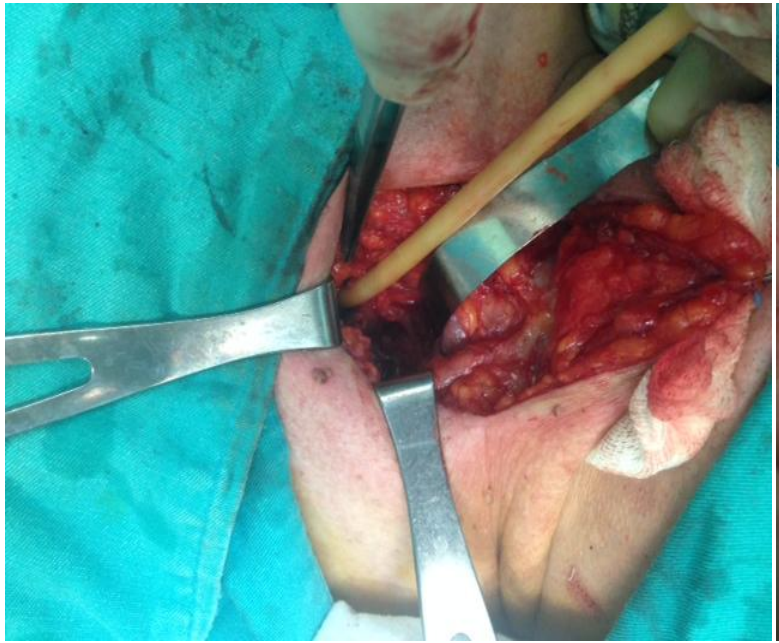

A

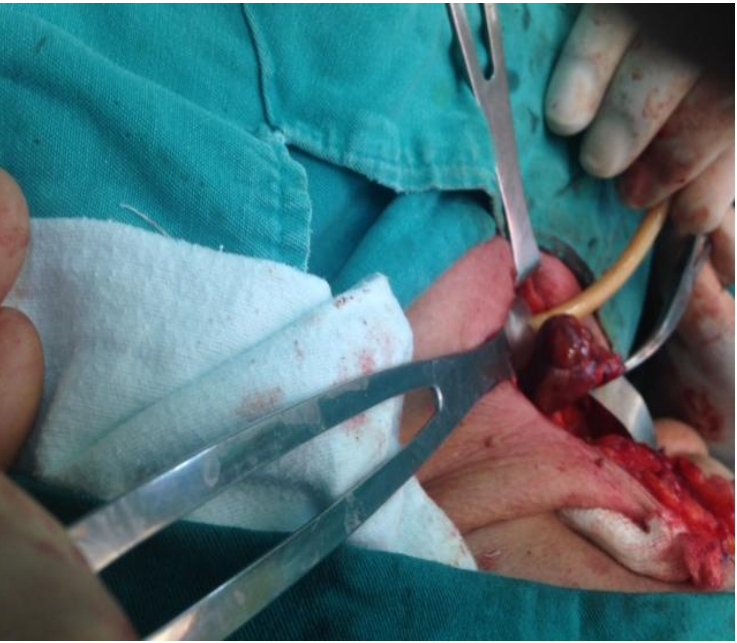

B

Figure 2: $A$ and $B$ exploration findings

This is a novel way of dissection of mediastinal parathyroid adenoma when its location is impossible to reach without sternotomy and if parathyroid gland is considered to be desended from its original location in the neck.

\section{MEDİASTINAL BİR PARATİROİD ADENOMU REZEKSIYONU}

60 yaşında yorgunluk ve böbrek taşı hikayesi olan bir bayan hasta. Serum kalsiyum ve paratormon seviyeleri $11.45 \mathrm{mg} / \mathrm{dL}(8.6-10.2)$ ve $464,7 \mathrm{pg} / \mathrm{mL}$ idi. Klorid/fosfat oran1 69,9 iken tübüler fosfat emilim oranı \%56 idi. Boyun ultrasonografisi normaldi. Paratiroid sintigrafide sol tiroid lobu alt polden mediastinel bölgeye trase şeklinde uzanan bir kitle tespit edildi. Boyun ve toraks CT görüntülemede aortik arkın altında, nodüler, tiroid lobu ile izodens, yaklaşık $26 * 27$ mm'lik bu kitle ile komşulukta $13 * 11 \mathrm{~mm}$ boyutlarında ayrı bir hpodens nodül saptandı.

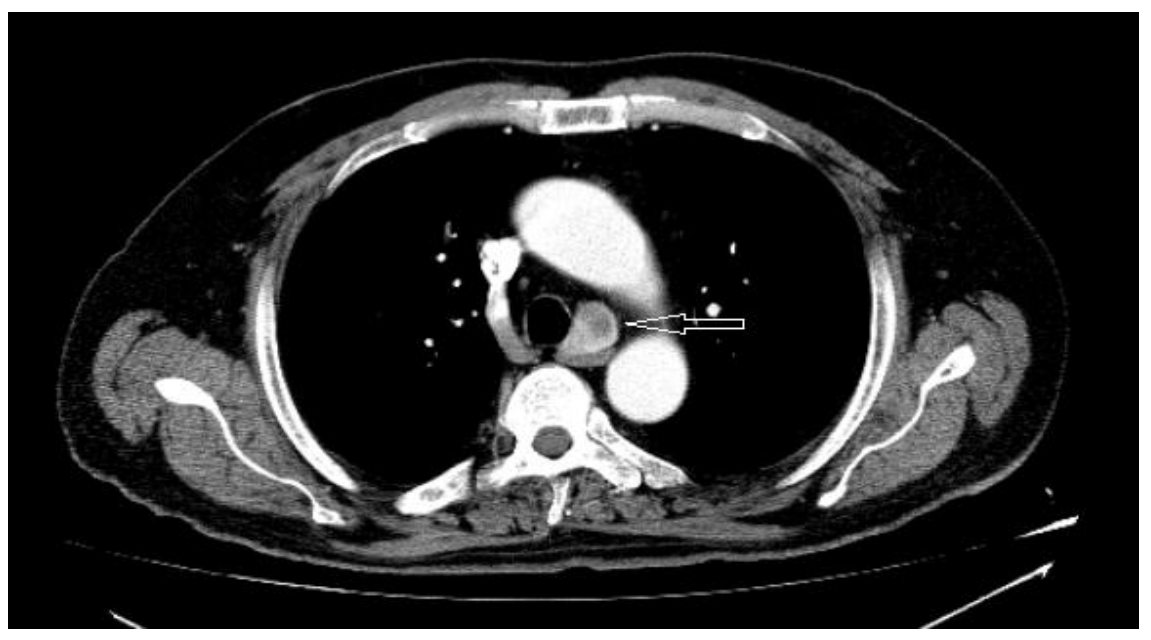

Resim 1: Bilgisayarlu tomografide paratiroid adenomu

$\mathrm{Bu}$ doku sol tiroid lobuna tubuler bir doku ile bağlıydı. $\mathrm{Bu}$ bulgular mediastinel bir paratiroid adenomuna ile tutarlılık göstermekteydi. Cerrahi esnasında, adenomun üst kutbu eksplore edildikten sonra, kitleye foley kateter balonu kullanılarak künt diseksiyonlarla ulaşıldı. 



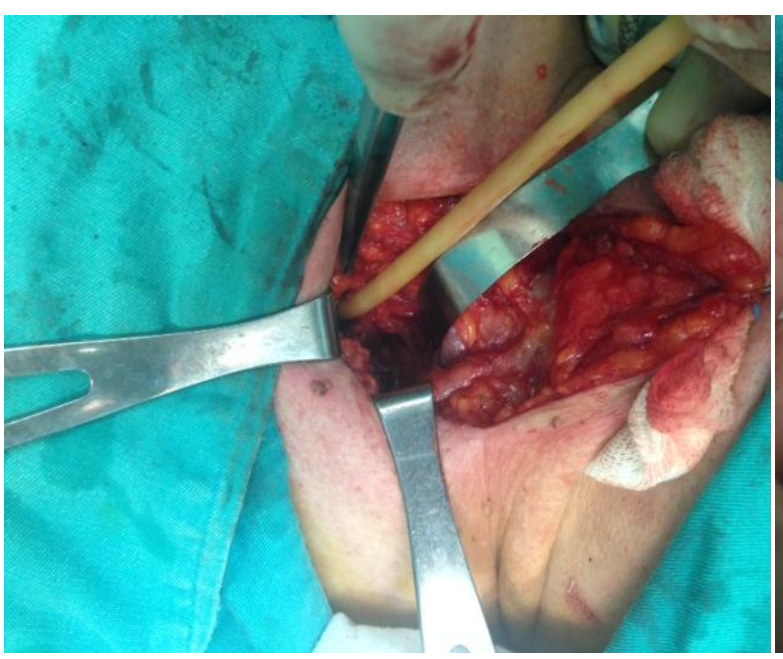

A

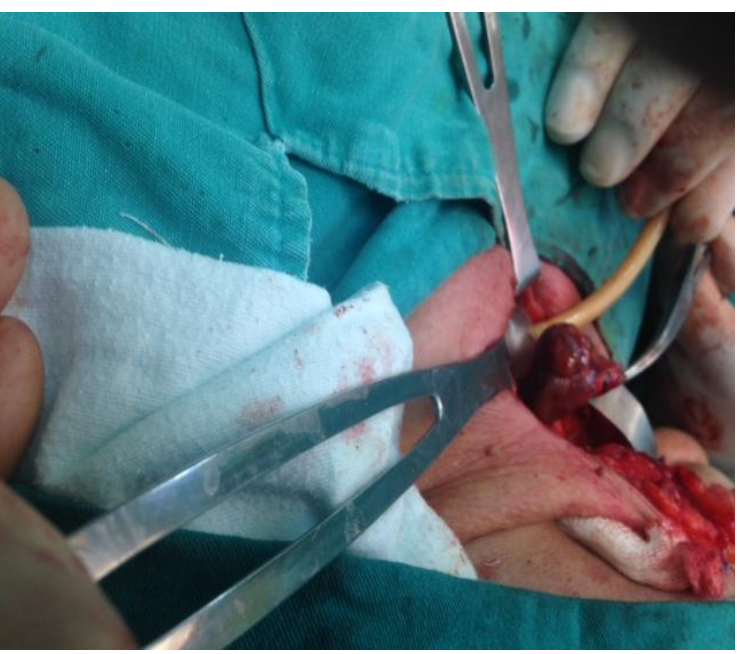

B

Resim 2: A ve B araştırma bulguları

$\mathrm{Bu}$ yöntem mediastinel paratiroid eğer paratiroid bezi boyunda olmas1 gereken adenomunun diseksiyonunda eğer lokalizas- orijinal lokalizasyonundan daha aşağıda ise yonu ulaşmak için imkansız bir yerde ise ve kullanılan yeni bir yöntemdir.

\section{REFERENCES}

1. Crescenzo DG, Shabahang M, Gravin D,

Evans SR. Intrathyroidal parathyroid cancer presenting as a left neck mass. Thyroid 1998;8:597-599. 